\title{
Cinema as the Platonic Cave: French Thinkers' Views on Media Education
}

\author{
Alibek Serikbekovich Begalinov, Madina Serikbekovna Ashilova, Kalimash \\ Kapsamarovna Begalinova \\ Al-Farabi Kazakh National University, Kazakhstan. \\ Kazakh Ablai Khan University of International Relations and World Languages, \\ Kazakhstan
}

Received December 23, 2017; Revised March 10, 2018; Accepted March 20, 2018; Published May 07, 2018.

\begin{abstract}
The views of prominent French philosophers-poststructuralists on the nature of cinema, television and their connection with the system of modern education are explored in the article. The main goal of the research is to answer the question: can modern media act as a teacher? Do they have a positive impact on the upbringing process, or do they harm it? Each of the thinkers presented in the article has its own point of view. However, together they bring a general idea of interconnection and interdependence of media and education system. The novelty of the article is a scrupulous study of this aspect in the work of French thinkers, analysis, synthesis of their ideas and concepts, and, as a result, determining the influence of modern media on both education system and overall development of society.
\end{abstract}

Keywords: philosophy of education, philosophy of upbringing, pedagogy of perception, deconstruction of cinema, postmodern, cinema philosophy, pyrotechnic imperative, simulacrum.

\section{Introduction}

Even at the dawn of the twentieth century, Western philosophers J. Ortega y Gasset, G. Marcuse, M. Heidegger, O. Toffler and others anxiously spoke of a total onset of mass culture era, a formation of a mass man, which is a consequence of development of information and communication tools of society, essential attributes of which are conformism, consumerism. Today, in connection with commercialization and globalization processes of mass media, the task of investigating production and perception mechanism (perceptions) of media images, the entire media reality in the mind of a person, their influence on the upbringing and behavior of people, is even more urgent.

In solving this problem, Western school has succeeded a lot, especially French philosophers and postmodernists. Let us emphasize that the contrariety of postmodern philosophy, its relativistic and Nietzschean positions of extreme nihilism, the loss of faith in reason and humanism require the critical approach to the evaluation of this philosophy, the analysis of its concepts from the standpoint of dialectical materialistic methodology. However, this does not underplay the importance of French philosophical school's ideas for social philosophy. They showed that modern man can "be", being only "mediated". Therefore, the main trends in the (c) AesthetixMS 2018. This Open Access article is published under a Creative Commons Attribution Non-Commercial 4.0 International License (http://creativecommons.org/licenses/by-nc/4.o/), which permits non-commercial re-use, distribution, and reproduction in any medium, provided the original work is properly cited. For citation use the DOI. For commercial re-use, please contact editor@rupkatha.com. 
development of modern education are informatization, mediation, communicative, technicism. They revealed not only creation and perception mechanism of media images, but also important characteristics of sociocultural space of capitalist society that promote "dehumanization of man", convincingly demonstrated the role of cinema in problem solution of "humanization of dehumanized person". "Today technology discourses cover both speculation and politics. The shift from industrial culture to media culture, information culture, and technology culture is a phase shift of frightening proportions, "T. Drakri notes [1].

The article studies the value aspects of media education in the theories of prominent postmodern scientists $[2,3,4]$, it analyzes the influence of media reality on society development, the features of figurative perception of reality are revealed through the mass media.

\section{Methods}

The following methods are used as a methodological basis:

- dialectical methodology, systemic, structural-functional and activity-based approaches, principles of objectivity, overall connection and development, inconsistency, determination, unity of historical and logical. The system method allowed giving an objective description of both internal and external links in media education process, it allowed to show the interrelation of various factors in the construction of media education space.

-structural-functional and activity-based approaches formed the basis of proposals formation on improving the process effectiveness of interaction between traditional and media sides in media education. A person-oriented approach is used to study the nature of the impact of traditional and media resources on human in the course of media education;

-general scientific methods of cognition: induction and deduction, analysis and synthesis, comparison, analogy, extrapolation, generalization, interpretation, comparative-historical, problem-thematic, structural, observation, study and generalization of educational experience of universities, analysis of source study base and others.

The theories developed in the works of prominent French philosophers A. Bergson, G. Deleuze, J. Derrida, M. Foucault, J. Baudrillard and J.-F. Lyotard form the theoretical basis of the article.

\section{French thinkers about cinema and education system}

First, the specificity of communicative nature of media culture is cinema and television language, which have unlimited communication possibilities and mass character of cinema and tele-shows perception, in the framework of which new meanings of collective being and specific representative forms of world understanding are appearing, that come out from probability, "film reality" (A. Bazin) taking place on the screen. From the point of view of an ontological criterion, mass communication is a process of mass social communication intermediated by special techniques, a way of recording and broadcasting of the cultural information [5, p. 46].

"The communicative specificity of this process," -O. Nechay notes, "is conditioned by the peculiarities of technology that allows materializing, replicating in the form of identical copies, storing and constantly delivering information (including simultaneously - in real time) to a mass 
audience. From the point of view of the chronotope, the mass communication is inclusive in space, infinitely long and super operative in time "[6].

The main elements of communicative process are a communicator, a media content, a communication channel and a communicant. The communicator creates content support using communication channels, sends it to the communicant, realizing its goals, or satisfying the requests of the communicant. The mass audience for the text sender is anonymous, dispersed, and the communication itself is network, scattered in space, with weak and delayed feedback. The mass audience by levels consists of macro groups, micro groups and individual addressees.

All three addressees absorb (often indiscriminately) texts and pictures prepared by the communicator and delivered through movies, television, Internet, often without thinking about purposes and functions of the received content, that the copy of the surrounding reality offered to him cannot completely coincide with the original.

Sometimes created simulacra are the images that do not have designators in the surrounding reality (for example, a virtual person). "There is no original, the reproduction of which would be an image. Images live their own lives. Nevertheless, this does not mean that there is no reality. The simulacrum does not deny it. It claims to have an ontological status himself " $[7$, p. 9].

French philosophers point out that today, under the influence of mass media, not only the content of education and upbringing, the forms and methods of transferring knowledge, but also the traditional teacher-student relationship is changing. Today, the process of identifying the Teacher is difficult. "Who is the teacher?" - It is a question that largely shapes the "I" of the speaker. My own self remains dependent on the name of the teacher (which can be likened to "the name of the Father" in psychoanalysis), structuring that space where the action has yet to be accomplished. In fact, it turns out that pedagogy justifies itself by the fact that the Teacher is identified in the work of the other, and the method of this identification does not matter "[8, p. 39].

The system of upbringing and education has moved beyond the framework of educational and pedagogic institutions. Knowledge, educational values and experience go on the air through various channels and different means. With the development of digital television, Internet and other information technologies, cinema has become a part of our lives. Moreover, cinema clearly demonstrates the disappearance, the distance of traditional teacher, mentor, and guru. Coming out of the depths of mass culture and entertainment industry, cinema is more than just an art form.

Some researchers note that pedagogy has acquired a technical form of thinking since the days of Socrates. Thus, V. Yeager, tracing the "internal reform" of paideia in the ancient Greeks in the IV. B.C.E., notes the change of educational tendencies to educational, aimed at finding the truth (Socratic "goal of life"), to build a new society and educate not all citizens, but, above all, its rulers. In addition, paideia, being a creation of poets, passed into the hands of scientists and philosophers for many thousands of years [9, p. 10].

Today, paideia returns to the old direction of art. Moreover, pedagogy with a technical way of teaching knowledge, skills and skills, moves to completely new ways of translating knowledge and experience. For example in cinema, this translation takes place with a direct way- without revealing itself. Even without the knowledge of specific movies, writes G. Deleuze, every person who has ever looked at the screen already has a cinematic experience. 
It is an experience of cinema perception, or as it is still called the experience of perception. It is pretty simple and easy to go on the air. Because unlike the school, knowledge and experience in cinema are transmitted not through training, but through entertainment. The cinema not only translates the experience, but is also a platform in which knowledge, values, norms test themselves for vitality and sustainability.

At the dawn of cinema creation, in 1936 Walter Benjamin wrote:

"In entertainment, which can offer art, they casually check how the new problems of apperception became resolute. Since an individual always has a temptation to deviate from solving similar problems, then art takes on the most difficult and important where it can mobilize the masses. Nowadays it does it in cinema. Perception in the entertainment process, which attracts the attention of the public in all areas of art, is a symptom of profound changes in apperception; it has its own training tool - the cinema "[10, p. 166].

The author noticed very accurately that in the conditions of cinema the role of a teacher is assumed not by the director, producer or scriptwriter - but by the viewer. Moreover, not a single viewer, but a mass audience, a crowd. If the crowd is carried away by the motion picture, emotions and feelings awaken in it, and then its student (the author of the film) coped with his task. In other words, cinematic education is carried out through cinema capture, development of cinema sense, which is directly related to the enjoyment of the viewers. "The largest American directors are able to become students of the viewer" [8, p. 40].

\section{Henri Bergson: about the cinematographic nature of thinking}

The greatest French thinker of the early twentieth century, Henri Bergson (representative of the "philosophy of life" and irrationalism) noticed a special relationship between cinema and thinking in the works "Matter and Memory", "Creative Evolution". Cinematography was for Henri Bergson a brilliant visual tool to show how our minds are arranged and how our mind works. In "Creative Evolution" he wrote that "mechanism of our ordinary knowledge has a cinematic nature" [11, p. 37].

Criticizing the cinema, A. Bergson consistently conducts criticism of mind and intellect. The key category of Bergson's philosophy is the movement in the state of which our life and our consciousness are located. "In this way, we can say about life, as well as about consciousness that it is doing something every minute" [11]. However, the weakness of human intellect lies in the fact that it is unable to comprehend the world in motion, it stops the movement, decomposing it into moments of rest, disjoints the complex and changeable, reducing it to the simple and resting. However, where there is no movement, A. Bergson writes, there is no life. Therefore, our brain and science in fact deal with the already dead, immobile nature. In order to comprehend life, it is necessary to learn to comprehend nature in motion, that is, in its natural state.

In his opinion cinema also gives us a false movement, its cinematic illusion, it restores it mechanically by "scrolling a string of images", combining shots with "fixed sections" from moving reality. Our thinking, our intellect works in the same way, reproducing a mobile life in its consciousness, isolating and memorizing the most important moments for their reproduction at the right time.

"We are making a kind of snapshots of a fleeting reality and, as they characterize this reality, we are satisfied by threading them onto an abstract, continuous and invisible becoming located in the bowels of the cognitive apparatus ..." [11, p. 79]. 
As a result, A. Bergson concludes that our consciousness works on the principle of cinematography - it divides reality, allocates privileged events from it (fixed sections) and connects them together. It turns out something like a movie, where the edit is carried out by the intellect.

Bergson's ideas, in spite of his criticism of cinema, are extremely important for our understanding of the connection between cinema and thinking, the connection between cinema, education and upbringing. Cinematography became for him a visual means to show how our consciousness works, that it has a cinematic nature.

Intellect also divides reality into fixed sections, separates special moments from it "selective Being" and unites them, cinematically reproducing the life. But cinematography is a false movement, which denies it as a means of education and upbringing of the individual. The comprehension of life, A. Bergson believed, is given to man only in its experience, and this is not someone's experience, but my own.

Modern philosophers, criticizing A. Bergson, show that cinema is able to generate "imagemovement" and is an amazing opportunity for pedagogy, enhances the opportunities to learn and teach through intuition. It is an education of experience, or how G. Deleuze calls it - "pedagogy of perception", which is capable of giving a person an invaluable experience of perception, experience of life.

\section{Gilles Deleuze: cinema and "pedagogy of perception"}

In the work "What is philosophy?", written by him in collaboration with the psychoanalyst F. Gvarttari, Deleuze defines the role of philosophy in the modern world, he notes that "... philosophy is not a contemplation, as contemplations are themselves things considered in the course of the creation of corresponding concepts.

Philosophy is not a reflection, since no one needs philosophy to ponder over something; declaring philosophy an art of meditation, it is rather belittled than elevated, because pure mathematicians did not wait for philosophy at all to reflect on mathematics, like the artists about painting or music; it is a bad joke to say as if they are becoming philosophers, so intrinsically their reflection belongs to their own creativity. Philosophy does not take final refuge in communication, which potentially works only with opinions, in order to create a "consensus", and not a concept, as a result "[12, p. 14]. Further: "Concepts always carried and carry a personal signature: Aristotelian substance, Cartesian cogito, Leibniz monad, Kantian a priori, Schelling potency, Bergson duration" [12, p. 21].

Today, various disciplines try to eclipse philosophy, reduce its role or reduce to disappearance but, as Deleuze shows, they deal only with simulacra of philosophy, copies that do not have the original.

"It came to complete shame when the very word "concept" was captured by informatics, marketing, design, and advertising - all communication disciplines that declared: it's our business, we are creators, and we are conceptors. We are friends of the concept, because we introduce it into our computers "[12, p. 28].

G. Deleuze argues that no science, no art, including sociology, linguistics, and psychoanalysis, which each claimed to be exclusive and comprehensible in its time, can substitute for philosophy, understood as creativity and the creation of original concepts. 
"... As long as there is time and place for the concepts creativity, the corresponding operation will always be called a philosophy or it will not differ from it, even if they gave it another name" [12, p. 28].

According to Deleuze, philosophy should not search the uniform traits in things, but reveal the features of differences and repetitions in them. G. Deleuze reviews cinema as a continuation of philosophy, as a continuous element of movement and changeability, as a special way of perceiving the world, which is not given by science.

"Precisely because the matter of cinema is the space of the relationship between the forces of perceptions (intensities), affects and desires ... cinema is not just a" return of reality ", not just its exact reproduction, but such a return, when only the private, only selected by desire, returns", p. 17].

"The cinema itself," he notes, "represents a new practice of images and signs, and philosophy must create the theory of the latter as a conceptual practice" [14, p. 614]. G. Deleuze sees cinema through production of image-motion and image-time in their movement and variability. The philosopher believes that viewer's perception is built according to the rules of framing, panning, editing. These three points together constitute Deleuze's "perceptual pedagogy", directed at the new subject of perception, which is the mass (mass viewer).

"Deleuze's idea is that the image in the cinematography is formed not by the movement image, but by a movement that is incapable of forming an image as an imagerepresentation, simulacrum-image, on which the art has always relied and with which phenomenology deals "[13, p. 19].

Unlike philosophy, which attached special importance to high spirituality and morality, cinema is not necessarily addressed to high values. In addition, people usually go to cinemas, not for high knowledge, but for entertainment and pleasure. However, this does not prevent cinema (not every but classical movie) from performing educational and educational functions. The movie is understandable and accessible to everyone.

Through interaction and playing in the movies of various images-movements, images-time, images-emotions, etc., cinema is able to form its subject. Since people lost their ability to listen to writers and philosophers who were "doctors of civilization", film and television directors adopted the healing function, where G. Deleuze laid the task of educating the masses, teaching them "pedagogy of perception," and correct perception of the cinema. Gilles Deleuze sought to understand the relationship of cinema and philosophy, he thought of cinema through the cinema and philosophy.

\section{Jacques Derrida: deconstruction of cinema and education "bypassing words"}

In contrast to G. Deleuze, who made a bet on cinema technique and images system creation, Jacques Derrida shifts the research emphasis to psychology of perception of media images. He finds out how much movie has changed the psychotype of a person and how it affects the formation of man's imagery and education ("Memories of the blind," "Television Echography," "Take the words out" etc.) $[15,16,2]$. Drawing on his rich experience as a filmmaker, Derrida argues that modern youth is taught and educated through movies. Cinema pedagogy is strikingly different from other types of upbringing, since it is obviously impossible to fix and memorize the material. Movies do not remain in the memory of a person, in most cases, he simply forgets them. Cinema does not compete with literature and theater, its content is often not fixed by memory. 
Its value and specificity lies in the possibility of a special "experience" of the seen, in the desire to see and know what is not taught at school and does not tell in the family what can be acquired and learned only alone, with pleasure, through one's own experience and empathy.

"Sensual and erotic culture is instilled in us precisely by cinema. What a kiss is, we first learn from the screen, and then only - in life, "- says J. Derrida [17].

And further:

"Having found myself in the dark of the cinema and having the opportunity to" spy ", I enjoy unlimited freedom, not constrained by any prohibitions. The viewer in front of the screen is an invisible voyeur, he is allowed any fantasies, he can identify himself with anyone and anything, and all this without the slightest effort and without asking anyone for permission. $"[17,95]$.

That is why, Derrida writes further, the cinematic experience cannot take the form of knowledge in our ordinary understanding and be assimilated by memory. It refers to a completely different field - the psychology of man and works on the principle of the unconscious.

"Cinema remains for me a pleasure - hidden, secret, greedy, insatiable and, consequently, infantile. Therefore, it should remain this way" $[17,96]$.

Revealing the specifics of the cinema, J. Derrida emphasizes that cinema is very similar to Platonic cave; it is filled with all sorts of ghosts, which now and then appear in various films and TV programs. The very structure of film image is ghostly; the image initially exists together with ghosts. "The cinematographic experience," writes Derrida in "Television Echography," is really wholly permeated with illusions "[17, 95].

And further:

"On the screen in front of the viewer, as in Platonic cave, there are visions: and he believes in them, and sometimes he worships. Since illusory as such cannot be reduced to the dead, either to the living, or to the perception, or to the hallucination, then the way of believing in this illusory must be explored in some new, completely original way "[17, 95].

In many ways, they go to the cinema to relax, to put their thoughts in order, to be alone with themselves, in Derrida's words "to give shape and word to ghosts living inside" [17, 95].

J. Derrida highly appreciates historical cinema, but regrets that directors often display not joyful events from the past, but, on the contrary, the most dreary and sad, which turns cinema into a "ghost memoir", "the majestic work of sorrow". The movie image differs from the images of other arts in that it is syncretic - it links together the authenticity and illusion, reality and deception, giving the viewer the possibility of endless interpretation and guesswork about what is in the cinema or television the truth and what is fiction.

The dual nature of cinema, directed at once to all and only one, allowed a person to realize his old dream, which could not be realized by other arts: literature, painting, theater, poetry, and philosophy - communication with ghosts.

One of the main concepts of J. Derrida's philosophy is the "deconstruction" of cinema, which he considers in relation to the deconstructive type of writing and compares it with the disassembly assembling of mechanisms. In cinema, like in the deconstructed letter, there is no hierarchy, rigid centering. Each frame and movie episode is equally necessary and equally important. Moreover, deconstruction in cinema overthrows the dominant of discourse, which 
prevailed in the letter. The words in movie, introduced by the director, become an inseparable part of the movie image and act more on emotional component of the human mind than on his consciousness. If upbringing and education within the walls of educational institutions is based on discursive communication of the student and the teacher, the letter is a measure of literacy, and words are the only tool for teaching and upbringing, then cinema pedagogy is based on a completely different type of upbringing.

It is an education without words, education bypassing words, education by experience and complicity in what is happening. According to J. Derrida, if the director chooses words, these words are purely "cynical", short, concise, most comfortable and beautiful. "To take the words out means to find phrases that would not be a bargaining chip of lectures, courses and conferences" $[17,96]$.

At the same time, J. Derrida warns that it is impossible to completely trust cinema in education of youth and primarily because pedagogy is inextricably linked with politics, that the authorities usurp all media, including television and cinema. On television and in cinema, images and subjects that are pleasing to the authorities go on the air, that type of person and that type of relations between people that the authorities need and are in demand are cultivated. "Power," writes J. Derrida, "appropriates in advance the future: the past, the future, and the present are confiscated by it. We know perfectly well that there are no innocent archives "[17, 95].

\section{Jean Baudrillard: is it possible for cinema and television to educate a person?}

Another greatest thinker, "guru" of postmodernism, Jean Baudrillard shares the ideas of J. Derrida about appropriation of present and future by power and mercilessly criticizes the very power and Western society for the complete loss of reality, for the creation of "hyperrealism" in which everything is reversed and the human is destroyed as a subject of society. Death in the philosophy of Baudrillard becomes the last bastion and appears in the form of a representation, "fantasy", "simulacra", which disturb the consciousness of the masses and, thereby, allow a person to survive. The world of signs-simulacra today filled all spheres of human activity.

They are found everywhere - in art, media, language, power, movie and television. The significance of any thing, its value is now measured not by its utility and purpose, but by its image, sign, brand, and "simulacrum". Nothing now costs neither things, nor human relations - all have been replaced by their simulacra and brands. Not knowledge, skills and experience, as before, but the presence of things that have a sufficient set of simulative images becomes the main means of self-expression and identification of a person in the conditions of consumer society, the entertainment industry and mass culture. J. Baudrillard calls simulacrum as an evil, a unit of sign system, a false likeness, a copy hiding the original absence $[3,18,19,20]$.

A passive and obedient mass is the most devoted and grateful student and consumer of hyper reality, simulacra. Moreover, it does not need historical movies (like J. Derrida), but horror movies, wars and disasters, which it perceives with indifference and even with pleasure. Demand creates a proposal: blockbusters, action movies, thrillers, horrors and other genres of cinema.

"It is the aesthetics of destruction that becomes the most attractive for modern cinema, operating with direct impact technologies [...] The need for catastrophe, destruction, ruin and indifference- is not it a true catastrophe, invisible, but absolutely real?" The thinker asks [21, c. 263]. 
From this standpoint, the author's point of view is clear, considering that cinema and television do not educate, but degrade a person, make him a hypocritical, evil, impoverished spirit. In the lecture "Evil demon of images" Baudrillard analyzes the state of mass culture, states that it is completely absorbed by simulacra.

Images of simulacra, especially those living in movies and on television, outpace the reality, tear the cause and effect, destroy the habitual representations of the person about good and evil, justice and injustice, in other words - simulacra are anti-pedagogical and do harm to the person. Baudrillard shares M. Foucault's idea that "microphysics of power" ensures the functioning of an "inquisitorial civilization" and a "disciplinary society" similar to a prison. However, it is not fault of cinema and television programs for moral decadence (they are only consequences) but the ubiquitous images of simulacra that have taken the place of reality through the impact on the unconscious in man.

"The reality is lost. Nevertheless, the reality is not simply lost, the character of causality changes. It is not the image that follows reality, but, on the contrary, it generates it "[21, p. 263].

Through the cinema and television impact analysis on human, J. Baudrillard draws man's attention to the falsity of values, the falsity of the simulative reality that lead to an anthropological catastrophe. Only realizing the fullness of destructions that occur not on the screen, but in the souls of people, a person will be able to look back and enter upon the actual path.

We completely share the way out of the environment of "carnival simulacra" proposed by J. Baudrillard through understanding and actualization of what has been displaced by simulacra the deep problems of cultural existence, universal human values in upbringing and education of the individual. This should be done by social philosophy.

\section{Jean-François Lyotard: what is the secret of the vitality of cinema and television products?}

The other major philosopher of modern times, Jean-François Lyotard, continued the line of criticism of the modern world order of J. Bordillard with a slightly different attitude. The name of his world-famous work "The state of postmodern" speaks for itself. However, it is often called a "treatise on knowledge", because it is aimed at studying the transformation of knowledge, changing its nature, status and role in the postmodern era. Within the framework of this goal, the subject of his research is also the philosophy of education, its relationship with cinema and television, which for our research is of some interest. Here we will consider his concept of cinema through the concept of "pyrotechnic imperative", the possibilities of using cinema and television in the sphere of education and upbringing, views on the correlation of cinema, ethics and upbringing. Among the diverse and versatile scientific works of French philosopher, there is only one small work devoted to cinema - "L'acinema", published in 1973.

The impetus for its writing was the work "Cinema" by G. Deleuze and the theory of images developed by A. Bergson in his work "Matter and Memory". Starting from the arguments of these philosophers, J.-F. Lyotard analyzes the role of cinema in modern information world and shows its influence on morals, ethics, and knowledge. Following G. Deleuze, he does not agree with A. Bergson that the images are simply revealed in cinema. Images-movements, images-time, imagesaffects, etc., are not simply found in movies, they exist there permanently. 
Cinema is not just a copy or simulacrum, it is a special matter in which various images fully exist and fulfil themselves. In the work about cinema, Lyotard attempts to designate this layer of cinematic imagery, which, like hypnosis, envelops the attention and mind of the viewer. With it, the philosopher writes, the mystery of the special appeal of the cinema is connected. This statement is also effective in relation to television. Indeed, unlike an unwanted book that the reader will no longer open and read, film and television products are more vital and repeatable. Unlike the theatrical action, ballet production, opera, where everything is thought out and played from beginning to end, cinema and television leave for the viewer certain random images, moments, signs, figures in a chaotic, random, unpredictable order, like the life itself. These images do not even participate in spectacle creation, but it is they that cause the special appeal of film narration.

They do not participate "in productive process," they do not fit into "productionconsumption economy", but are "unproductive movements" that arouse love for them. "It is superfluous that what does not participate in the production-consumption regime is the economy of desire, which always arises out of the framework of needs, which determines not the value of the object, but the love for it" [4; 22; 118]. This "economy of desire" Lyotard calls as "Libidinal economy." The French philosopher unexpectedly touches upon the problem of "sublime" here. Lyotard returns to the lost mass culture of this category and emphasizes its importance in education. Unlike the sense of beauty as the property of individuals, narrow groups, the sense of the sublime is the property of the whole mass. It is not divided, but for all it is "their own".

The sublime is found in cinema in the world of signs, scattered moments (formless), which on the one hand, cause rejection in us, and on the other - incredibly attract. Both repel and beckon simultaneously. It is these scattered signs that are the reason why cinema and television are infinitely scolded, but at the same time constantly watching. The viewer is not in a position to control desires and becomes a hostage of media products. In the bosom of cinema and television hypnosis are all spectators without exception who are not averse to "... resent vulgarity, but to catch every moment of its appearance on the screen" [4; 22; 122].

\section{Conclusion}

As a conclusion, let us emphasize that the ideas of prominent postmodern scientists have a significant significance for the development of media education theory. Educational media content changes the "psychotype" of a person, shapes his imagery, and generates a significant educational effect. At the same time, media devices can be used to manipulate the mind, destroy the habitual representations of a person about justice and injustice, about good and evil, and hamper his self-identification. In bourgeois society, everything is feigned, from material to spiritual production. The simulacra help the powerful to manipulate and control the mass consciousness, to build the social strata reproducing the simulation in society in the role of integrators of the society (instead of intellectuals), to keep subordinate workers in dispirited conformity, to increase virtual fictitious capital of separate groups of persons, etc. The simulacra revolution is already taking place on the expanses of Russia and Kazakhstan, which can radically change the way of life and the spirit of our peoples, the archetypes of traditional cultures and destroy educational traditions through their filling with simulacra and complete unification, deindividualization of cultural and educational spaces.

The prevention of this global threat for us depends on the results of the struggle of supporters and opponents of society's complete virtualization, the substitution of objective reality 
by simulacra. Respondent divides the authors' idea that the philosophy, understood as creativity and the creation of original concepts (J. Baudrillard, J.-F. Lyotard) determines the way out of the environment of the "carnival simulacra" created by the mass media. The further study of interaction mechanisms between educational subjects and media environment in the process of socialization of the person, the peculiarities of sensory and rational perception of media products, the nature of their influence on personality formation, the motivation and activity of a person in the process of media education, become the subject of social philosophy's special care in the conditions of factual, "multi-truth" world views. In media education, it is necessary to actualize the interest of educatee to deep problems of cultural life, the restoration of universal human values in the individual and public consciousness.

\section{List of references}

Druckrey T., Bender G., eds. Culture on the Brink. Ideologies of Technology. - Seattle, Bay Press, 1994. - 361 c.

Derrida J., Stiegler B. Echographies of Television: Filmed Interviews. - Wiley, 2002. - s.184

Baudrillard J. Simulacra and Simulation. - USA: University of Michigan, 1994. - s.165

Lyotard J.-F. L'acinema // Desdispositifspulsionnels. - Paris, 1973. - s.59

5. Shamshyn L.B. Audiovisual culture // Culturology. The twentieth century. Encyclopedia. - T.1. - St. Petersburg: University Book, 1998. - P. 46.

Nechai O.F. Perspectives: on television communication and aesthetics. - Moscow: Art, 2003. - p.119

Szpernalowski T. Problemy współczesnej kultury audiowizualnej. Mediaw kontekścieedukacji [Electronic resource]. - URL access regime: http://www.zsz7.pl/pdf/media.pdf (reference date 10.06.2014)

Aronson O. The feeling of cinema (notes on teaching) / / Cinematology notes. - 1999. - No 41. - P. 37 - 43.

Jaeger W. Paideia: the ideals of Greek culture. - UK: Oxford university press, 1965. - P. 6-12.

Benjamin V. The work of art in the era of its technical reproducibility // Cinematology notes. - No. 2. - M., 1988. - p. 166.

Bergson H. Creative evolution. - NY: Dover publications Inc, 2014. - s.375

Deleuze G., Guattari F. What is Philosophy? - London-NY: Verso, 1994.-s. 253

Aronson O. The language of time / / Cinema.- M .: "Ad Marginem", 2004. - p.392

Dzhurinskiy A.N. The history of pedagogy. - Moscow: VLADOS, 1999. - p.432

Derrida J. Memoirs of the Blind Memoirs of the Blind: The Self-Portrait and Other Ruins. - USA: University of Chicago Press, 1993. - p.141

Derrida J. Speech and Phenomena, and Other Essays on Husserl's Theory of Signs. - USA: Northwestern University Press, 1973.- p.166

Cinema and Its Ghosts: An Interview with Jacques Derrida - Discourse. -

Volume 37. - Numbers 1-2, Winter/Spring 2015. - pp. 22-39.

Baudrillard J. Symbolic Exchange and Death. - USA: SAGE, 2016. - s.280

Baudrillard J. The system of objects. - London-NY: Verso, s.217

Baudrillard J. The Consumer Society: Myths and Structures. - USA: SAGE, 1998 г. -s. 224 
Khudyakova L.A. Simulation and catastrophe // Social crisis and social catastrophe. Collection of mathematic conference. - St. Petersburg: St. Petersburg Philosophical Society, 2002. - P.262-264.

Aronson O. Ordinary sublime (cinema by J.- F. Lyotard) // Journal club Intelros. - 2008. - No. 2. - pp. 117126. 